\title{
Infectious diseases training in Canada: One size does not fit all
}

\author{
B Craig Lee MD FRCPC
}

\begin{abstract}
BC Lee. Infectious diseases training in Canada: One size does not fit all. Can J Infect Dis 2001;12(2):98-100.
PURPOSE: To evaluate training in infectious diseases, determining which components of the training program best prepare residents for their career choices and where improvements are needed.

METHOD: A cross-sectional survey was mailed to all 14 physicians who had graduated from both the Adult and Paediatric Infectious Diseases Training Program at the University of Calgary from 1985 to 1998. Responses about the adequacy of training were measured using a Likert-type scale and a qualitative questionnaire.

RESULTS: Of 14 mailed questionnaires, nine responses were received (64\%). Two-thirds of respondents were in an academic setting, and seven $(78 \%)$ graduates obtained postfellowship training. The specialists in academic settings were all engaged in multiple nonclinical activities. The clinical and diagnostic microbiological components of training received the highest scores in terms of adequacy of training.

CONCLUSION: Graduates of the University of Calgary training program indicated an overall satisfaction with their training. However, improvements are needed in career counselling, health administration, antibiotic utilization, infection prevention and specialized outpatient clinics. Potential strategies for addressing these issues include didactic lectures, enhanced exposure to clinical outpatient settings and provision of designated faculty mentors.
\end{abstract}

Key Words: Career Counselling; Infectious disease training; Survey

\section{La formation en infectiologie au Canada : un seul programme pour tous?}

OBJECTIF : Évaluer la formation en infectiologie en ciblant les éléments du programme de formation qui préparent le mieux les résidents à leur choix professionnel et ceux qui auraient avantage à être améliorés.

MÉTHODE : Une enquête ponctuelle a été mene, au moyen d'un questionnaire envoyé par la poste, auprès des quatorze médecins qui ont obtenu leur diplôme en infectiologie pédiatrique ou en infectiologie adulte à l'University of Calgary entre 1985 et 1998. Les réponses aux questions sur le caractère suffisant de la formation ont été mesurées à l'aide d'une échelle semblable à celle de Likert et d'un questionnaire qualitatif.

RÉSULTATS : Des quatorze questionnaires expédiés, neuf ont été retournés (64\%). Deux tiers des répondants travaillaient en milieu universitaire et sept diplômés ( 78 \%) ont obtenu une bourse de formation postdoctorale. Les spécialistes en milieu universitaire participaient à de multiples activités non cliniques. Les volets liés à la microbiologie clinique et diagnostique ont reçu les résultats les plus élevés quant au caractère suffisant de la formation.

CONCLUSION : Les diplômés du programme de formation de l'University of Calgary se sont montrés en général satisfaits de leur formation. Toutefois, il y aurait lieu d'améliorer l'orientation professionnelle, l'administration de la santé, l'utilisation des antibiotiques, la prévention des infections et les cliniques de consultations externes spécialisées. Figurent parmi les stratégies envisagées les exposés didactiques, la participation accrue dans les cliniques de consultations externes et l'instauration d'un programme facultaire de mentorat.

Department of Microbiology and Infectious Diseases, and the Department of Medicine, University of Calgary, Calgary, Alberta

Correspondence and reprints: Dr BC Lee, Faculty of Medicine, University of Ottawa, The Ottawa Hospital, General Campus, 501 Smyth Road,

Ottawa, Ontario K1H 8L6. Telephone 613-737-8880, fax 613-737-8925, e-mail clee@ottawahospital.on.ca

Received for publication February 28, 2000. Accepted May 19, 2000 
$\mathrm{T}$ he discipline of infectious diseases in Canada and the United States is relatively new. The subspecialty officially achieved recognition by the Royal College of Surgeons and Physicians of Canada in 1980 (1). In the United States, examinations to attain qualifications in the subspecialty were initiated in 1972 (2). Eleven institutions possess accredited training programs for adult infectious diseases in Canada (3), whereas there are an estimated 134 American training programs in adult infectious diseases (4).

Unlike the American programs, which have accumulated a myriad of career opportunities in academia, private practice or government (5), Canadian training has largely been restricted to an academic model (1). The apparent surfeit of infectious disease consultants and the fiscal restraints imposed on faculties of medicine, with the resultant detrimental effect on faculty recruitment, have led to dire proclamations regarding the future of the subspecialty $(6,7)$. However, the emergence of new infectious agents (8) coupled with the reorganization of health care delivery in both Canada and the United States would portend an increased demand for infectious disease specialists and a redefinition of their roles.

Such predictions insinuate that redesigning training curricula may be necessary. Retooling of the academic template requires an intimate knowledge of the ultimate career paths of graduates from training programs. The lack of published Canadian studies prompted a survey of the 14 past graduates from both the Adult and Paediatric Infectious Diseases Training Programs at the University of Calgary to assess the impact of these changes on the training of future specialists and to provide data to guide in the restructuring of training programs.

The prototypical profile of these graduates that emerged from this small study is that of highly adept clinicians and teachers who have completed lengthy training programs, are located in academic institutions and perform multifaceted roles.

Nine (64\%) of the 14 mailed questionnaires were returned. The majority of trainees who responded (71\%) have pursued postfellowship training in basic science disciplines. In $72 \%$ of these cases, the additional two to three years of formal training were supported by external funding, principally through competitive extramural sources (eg, Medical Research Council of Canada, Alberta Heritage Foundation for Medical Research). Using a Likert-type measurement scale, the clinical and diagnostic microbiological components of training received the highest scores. Most of the respondents (78\%) are currently affiliated with an academic department. The estimated total hours spent at work per week was 40 to $60 \mathrm{~h}$ for seven physicians (78\%); the two physicians who worked less than $40 \mathrm{~h}$ were women. The various roles served by academicians were reflected in the significant segments of time devoted to patient care ( $38 \%$ of the total time), teaching and administration ( $10 \%$ of the total time), and research (38\% of the total time). Although most respondents (89\%) were engaged in research, only a minority (33\%) were recipients of competitive research grants. Analysis of nonpatient care activities (exclusive of research and teaching), such as antibiotic utilization and infection prevention, indicated that this participation was insufficiently remunerated.

Although the training program was praised for its overall academic excellence, inadequacies were identified in the areas of: outpatient clinics specialized in travel medicine, human immunodeficiency virus, sexually transmitted diseases and home parenteral antimicrobial therapy; clinical epidemiology; health administration; infection prevention; and antibiotic utilization. These components of training warrant particular attention in view of the observation that a significant proportion of respondents have assumed these responsibilities. In addition, the expertise conferred by such activities has been forecasted to generate future employment and income opportunities $(1,9)$. The necessity for a broad array of specialized skills highlights the need for training programs to provide appropriate individualized career counselling. Several respondents of the survey commented on the importance of such a facet.

A disturbing observation revealed by the survey is the inability of a sizeable minority of graduates to secure an academic appointment as an explicit career goal. Deficiencies in career counselling, compounded by rigid adherence to the traditional formula for academic training, may account for this lack of fulfillment.

Strategies for improvement of the program have been implemented to address these concerns. Solutions include didactic lectures, enhanced exposure to clinical outpatient settings, provision of designated faculty mentors, the development of rigorously defined, rotation-specific objectives and the linkage of these objectives to evaluation.

The present investigation is subject to the potential limitation that the results may only be of parochial relevance. However, this survey represents a microcosm of infectious diseases training programs in Canada. This is supported by two lines of evidence. First, maintenance of a defined core curriculum is a requirement of program accreditation. Second, the specialty of infectious diseases in Canada has embraced an academic model (1). These considerations dictate a uniformity not only in program content, but in a focus on preparing trainees for academic careers. Indeed, an analysis of the membership of the Canadian Infectious Disease Society reveals a disproportionate number of members in academia (51\%) as opposed to private practice (5\%) (1). In contrast, a survey of 556 fellows graduating from infectious diseases programs in the United States between 1994 and 1996 found that graduates were equally distributed between an academic setting (42\%) and private practice (43\%) (4).

The findings from the present survey are a representative depiction of infectious diseases training in Canada. Health care reform, driven by continued economic pressures, will undoubtedly provide the incentive for the creation of new career opportunities for highly trained infectious diseases specialists (10). Such career pathways will likely deviate from the traditional, strict academic model. The increasing 
clinical demands exerted on this subspecialty will necessitate the development of unique career openings, likely with the incorporation of a 'blended' academic and private practice profile. The challenge for training programs in the next millennium will be to adapt to these changes to equip graduating fellows with the proper tools to seize and prosper from these opportunities.

ACKNOWLEDGEMENTS: The author thanks all of the former infectious diseases fellows who participated in the survey, Dr R Lewkonia for helpful advice, and Drs R Read and T Tadavji for their critical reading of the manuscript.

\section{REFERENCES}

1. Ronald AR, Nicolle LE, Goldsand G, MacDonald N. Infectious diseases as a Canadian subspecialty, with projections in the year 2000. Rev Infect Dis 1990;12:900-7.

2. Ronald AR. The reappearance of the specialty devoted to infectious diseases. Can Med Assoc J 1978;119:843.
3. The Office of Postgraduate Medical Education. Accredited Residency Programs. Ottawa: The Royal College of Physicians and Surgeons of Canada, 1998.

4. Joiner KA, Powderly WG, Blaser MJ, et al. Fellowship training in infectious diseases: A report from the regional and national meetings of infectious diseases division chiefs and program directors. Clin Infect Dis 1998;26:1060-5.

5. Hamory BH, Hicks LL, Manpower and Training Committee, Infectious Diseases Society of America. Infectious Disease manpower in the United States - 1986. 1. Description of infectious disease physicians. J Infect Dis 1992;165:205-17.

6. Ervin FR. The bell tolls for the infectious diseases clinician. J Infect Dis 1986;153:183-5.

7. Petersdorf RG. Whither infectious diseases? Memories, manpower, and money. J Infect Dis 1986;153:189-95.

8. Tenover FC, Hughes JM. The challenges of emerging infectious diseases. Development and spread of multiple-resistant bacterial pathogens. JAMA 1996;275:300-4.

9. Preheim LC. Career opportunities for infectious diseases specialists. Clin Infect Dis 1998;26:277-81.

10. Tice AD, Slama TG, Berman S, et al. Managed care and the infectious diseases specialist. Clin Infect Dis 1996;23:341-68. 


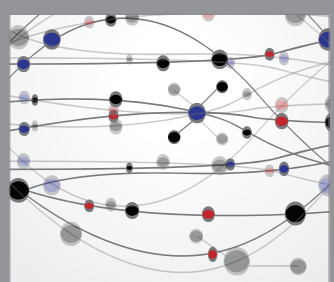

The Scientific World Journal
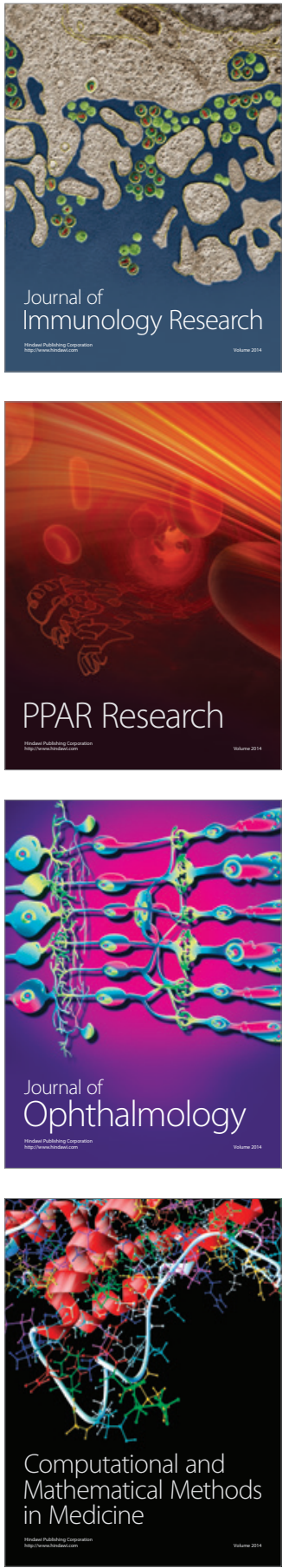

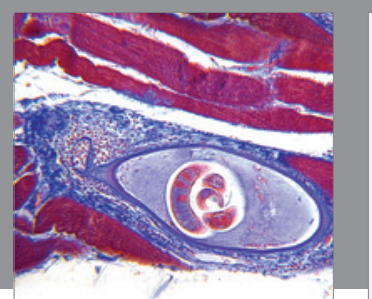

Gastroenterology Research and Practice

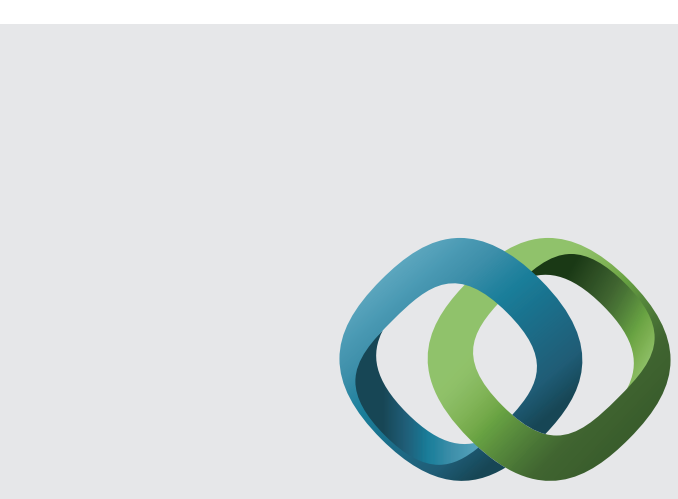

\section{Hindawi}

Submit your manuscripts at

http://www.hindawi.com
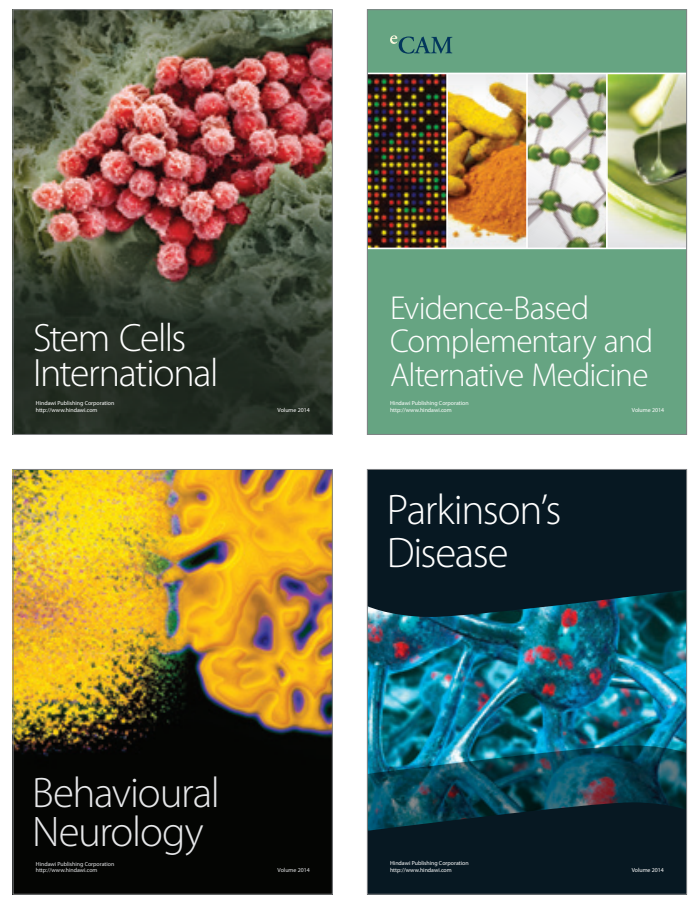
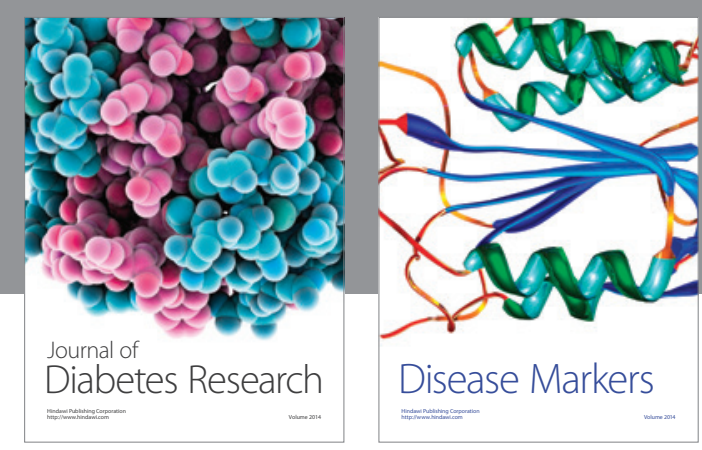

Disease Markers
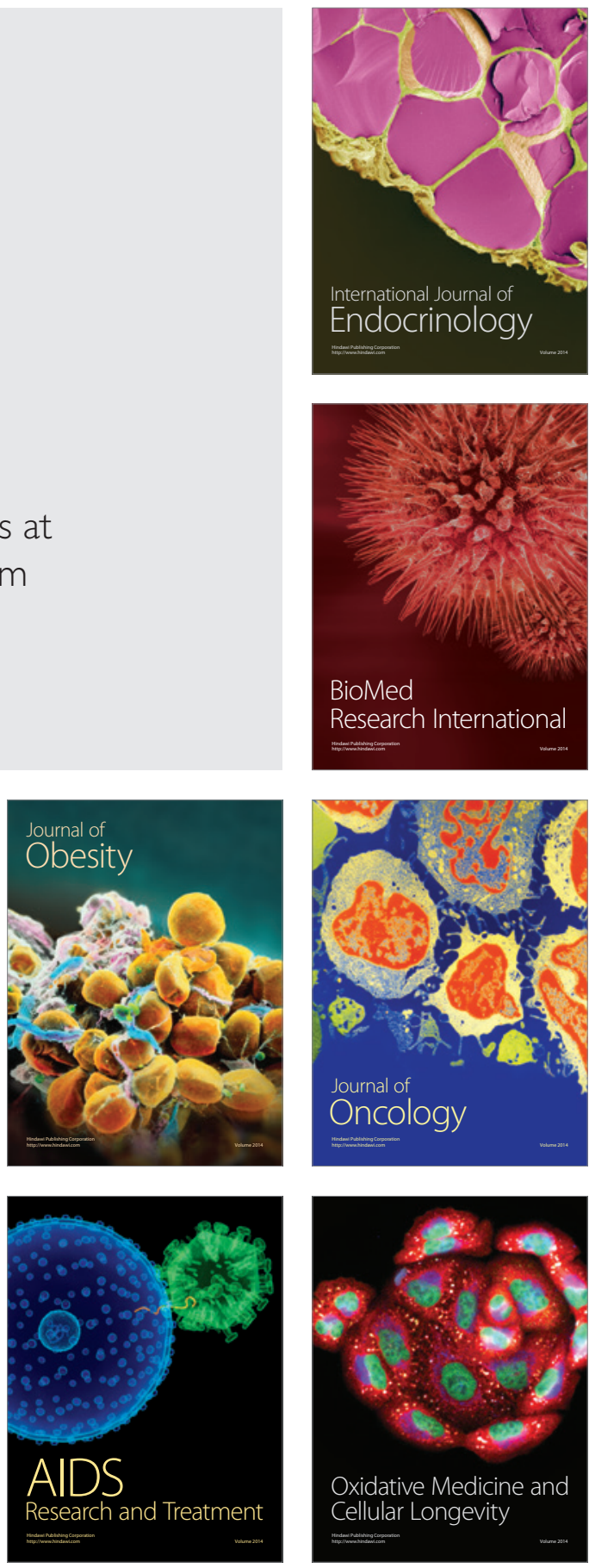